\title{
PERSONAS, KURU MANTISKĀS INTERESES AIZSKARTAS KRIMINĀLPROCESA GAITĀ VAI REZULTĀTĀ: TO TIESISKĀ AIZSARDZİBA
}

\section{LEGAL PROTECTION OF PERSONS WHOSE ECONOMIC INTERESTS HAVE BEEN INFRINGED IN THE COURSE OF CRIMINAL PROCEEDINGS OR AS A RESULT OF CRIMINAL PROCEEDINGS}

\author{
Ārija Meikališa, Dr. iur. \\ Latvijas Universitātes Juridiskās fakultātes \\ Krimināltiesisko zinātṇu katedras profesore
}

\section{Summary}

Today's criminal proceedings are characterised by a potential serious breach of economic interest, both in the course of criminal proceedings and as a result of such proceedings. This offence may also be extended to persons who have no direct connection with the criminal offence committed, such as family members of the accused, creditors, owners of the offence tools and others. The article deals with the question of whether a sufficient and effective legal protection of these persons is provided in Latvia.

Atslēgvārdi: mantisko interešu aizskārums kriminālprocesā, kriminālprocesā aizskartais mantas īpašnieks, aizsardzība kriminālprocesā

Keywords: infringement of property interests in criminal proceedings, owner of property infringed during criminal proceedings

\section{Ievads}

Mūsdienu kriminālprocesam raksturīga iezīme ir potenciāls mantisko interešu aizskārums, kas var notikt gan kriminālprocesa gaitā, gan tā rezultātā un skart arī personas, kuras tiešā veidā nav saistītas ar noziedzīgo nodarījumu, kā, piemēram, apsūdzētā gimenes locekḷus, kreditorus, noziedzīgā nodarījuma izdarī̌̌anas priekšmeta īpašniekus utt. Jebkuram aizskārumam no valsts puses jābūt tiesiskam, savukārt aizskartajai personai jānodrošina efektīva tās interešu aizsardzības iespēja, kā arī tiesības saṇemt kaitējuma atlīdzību, ja aizskārums no valsts puses bijis nelikumīgs vai nepamatots. Šì raksta uzdevums ir aplūkot, vai Latvijā ir nodrošināti pietiekami priekšnoteikumi to personu aizsardzībai, kuru ekonomiskās intereses ir skartas kriminālprocesa gaitā vai rezultātā. Šim nolūkam uzmanība galvenokārt pievērsta attiecīgo jautājumu tiesiskā regulējuma izpētei, nākotnes prognozēm un diskusijām, kas raksturo attiecīgā tiesiskā 
regulējuma tapšanu un saturu, kā arī kriminālprocesā nelikumīgi vai nepamatoti nodarītā kaitējuma atlīdzības problemātikai.

\section{Mantisko interešu aizskārums kriminālprocesā un aizskarto personu procesuālie statusi: vispārīgs raksturojums}

Saskaṇā ar Kriminālprocesa likuma (turpmāk - KPL) ${ }^{1}$ 1. pantu kriminālprocesa mērḳis ir efektīva Krimināllikuma (turpmāk arī KL) normu piemērošana un taisnīgs krimināltiesisko attiecību risinājums bez neattaisnotas iejaukšanās personas dzīvē. Kriminālprocesa mērķa sasniegšana nozīmē skart ne tikai iespējami vainīgo un cietušo, bet plašāku personu loku, ietekmējot tās gan procesa norises gaitā, gan tā rezultātā. Tas gan darāms bez neattaisnotas (nevajadzīgas un nesamērīgas) iejaukšanās personas dzīvē.

Situācijas, kad mantisko interešu aizskārums saistāms ar ko noziedzīgi izdarītu, nosacīti var iedalīt divās lielās grupās: aizskārums, kas radies noziedzīgas darbības rezultātā, un aizskārums, kas rodas kriminālprocesa gaitā vai rezultātā. Šajā rakstā uzmanība veltīta aizskārumam, kas rodas kriminālprocesā, tātad, procesuāli pilnvarotām personām īstenojot procesuālās darbības un pieņemot kriminālprocesuālos lēmumus.

Mantiskās intereses kriminālprocesā var tikt tieši ${ }^{2}$ skartas kā procesa rezultātā, tā arī tā gaitā. Tā mantisko interešu aizskārums, kas var rasties, kriminālprocesam noslēdzoties, ${ }^{3}$ ir:

- Krimināllikumāa ${ }^{4}$ noteikto mantiska rakstura sodu vai krimināltiesisko piespiedu līdzekḷu piemērošana;

- noziedzīgi iegūtas mantas atdošana vai konfiskācija (KL VIII. ${ }^{2}$ nodaḷa, KPL 27. nodal̦a);

- tāda noziedzīga nodarījuma izdarǐšanas priekšmeta konfiskācija, kurš var būt un var arī nebūt lietiskais pierādijjums (KL VIII. ${ }^{2}$ nodaḷa, KPL 12. nodal̦a);

- $\quad$ NIM aizstājējmantas piedziṇa (KL VIII. ${ }^{2}$ nodaḷa, KPL 27. nodaḷa);

- rīcība ar lietisko pierādijumu (KPL 12. nodaḷa);

- kompensācijas segšanas pienākums (KPL 26. nodaḷa);

- procesuālo izdevumu segšanas pienākums (KPL 29. nodaļa).

Savukārt vēl procesa gaitā aizskārums var rasties, veicot šādas darbības:

- kādas vērtības izṇemšana (ar izṇemšanu saprotot ne tikai atsevišķu izmeklēšanas darbību, bet faktisko darbību, kas var notikt kā izṇemšanas,

1 Kriminālprocesa likums: LV likums. Pien̦emts 21.04.2005. [03.03.2020. red.].

2 Šajā rakstā netiek skatīti gadījumi, kad kriminālprocesa rezultāts vai gaita var skart personas mantiskās intereses netieši, piemēram, situācijas, kad aizdomās turētā ievietošanas cietumā gadījumā tiek skartas viņa darba devēja mantiskās intereses vai kad darba devējam rodas izdevumi sakarā ar viṇa darbinieka izsaukumu dalībai kriminālprocesā utt. Tāpat arī netiek skatīti personu labprātīgi "uzṇemtie" mantiskie zaudējumi, piemēram, brīvprātīgi piesaistīta advokāta apmaksa. Tāpat apskatīti tie gadījumi, kad aizskārums cēlies no kriminālprocesuālas darbības saistībā ar izmeklējamu utt. noziedzīgu darbību, bet netiek skatīti tie gadījumi, kur aizskārums nav ar to saistīts, piemēram, mantas bojāšana vai iznīcināšana izmeklēšanas darbību laikā, kas ir atsevišķa pētījuma vērts jautājums.

3 Šajā rakstā ar "kriminālprocesa noslēgšanos" saprasta arī jautājuma galīga izlemšana par noziedzīgi iegūtu mantu, kas var notikt arī procesa gaitā KPL 59. nodaḷas kārtībā vai arī uz KPL 356. panta otrās dal̦as 2. punkta pamata.

4 Krimināllikums: LV likums. Pieṇemts 17.06.1998. [03.03.2020. red.]. 
tā arī citu izmeklēšanas darbību, piemēram, kratī̌šanas, apskates, utt. laikā) un neatdošana, t. sk. atzīstot to par lietisko pierādijjumu u. tml. (KPL 10.-12. nodal̦a);

- aresta uzlikšana mantai (KPL 28. nodaḷa).

\section{Personas, kuru mantiskās intereses aizskartas kriminālprocesā: to procesuālie statusi}

Ja kriminālprocess notiek tāpēc, ka kādas personas mantiskās intereses ir skartas ar noziedzīga nodarījuma izdarī̌sanu, aizskartā persona kriminālprocesā var ieņemt cietušā procesuālo statusu un aktīvi piedalīties kriminālprocesā, lai tā rezultātā gūtu savu mantisko interešu aizskāruma atlīdzinājumu. Šādas personas mantisko interešu piespiedu aizskārums kriminālprocesa gaitā, lai arī ne bieži, taču var rasties. Tomēr cietušà statusa esamība ir gana efektīvs savu interešu aizsardzības mehānisms, jo paredz salīdzinoši plašas pilnvaras kriminālprocesā.

Savukārt jau kriminālprocesa gaitā var notikt citu personu mantisko interešu aizskārumi. Ja kriminālprocesa gaitā un rezultātā tiek skartas tādas personas intereses, par kuru izteikts pieņēmums, ka tā izdarījusi noziedzīgu nodarījumu, šai personai ir personas, kurai tiesības uz aizstāvību, procesuālais statuss, kas atkal paredz plašas iespējas iesaistìties kriminālprocesā un aizsargāt savas intereses.

Taču kriminālprocesa gaitā un/vai rezultātā var tikt aizskartas citu personu, kuras nav ne cietušie, ne personas, kurām tiesības uz aizstāvību, intereses. KPL neparedz "trešo" personu institūtu (sal. skatìt Administratīvā procesa likuma ${ }^{5}$ (turpmāk - APL) 28. pantu, Civilprocesa likuma ${ }^{6}$ (turpmāk - CPL) 11. nodaḷu). Daļa no aizskartajām personām var piedalīties kriminālprocesā kā kriminālprocesā aizskartie mantas īpašnieki, dal̦ai statusa nav. Atbilstoši šĩ raksta tematikai tuvāk tiks apskatīta tieši to personu aizsardzība, kuras nav nedz cietušie, nedz personas, kurām ir tiesības uz aizstāvību.

\section{Kriminālprocesuālais statuss personām, kuru mantiskās intereses aizskartas kriminālprocesā, bet kuras nav nedz cietušie, nedz personas, kurām ir tiesības uz aizstāvību}

Jau iepriekšējās publikācijās ${ }^{7}$ esmu norādījusi, ka t. s. kriminālprocesā aizskartā mantas īpašnieka definējums KPL ir nepārdomāts un būtu pilnveidojams. Neatkārtojot izvērstu argumentāciju, kura rodama šajās publikācijās, jānorāda, ka joprojām šo statusu raksturo nepārdomāts terminu lietojums ("manta",

\footnotetext{
Administratīvā procesa likums: LV likums. Pieñemts 25.10.2001. [03.03.2020. red.].

Civilprocesa likums: LV likums. Pieņemts 14.10.1998. [03.03.2020. red.].

Sk., piemēram: Meikališa Ā. Kriminālprocesā aizskartā mantas i ipašnieka tiesiskais statuss un tā problemātika. Grām.: Tiesību efektivitāte postmodernā sabiedrībā. Latvijas Universitātes 73. zinātniskās konferences rakstu krājums. Rīga: LU Akadēmiskais apgāds, 2015, 81.-99. lpp.; Meikališa Ā. Kriminālprocesā aizskartā mantas ìpašnieka tiesiskais statuss un tā aktuālā problemātika. Grām.: Juridisko personu publiski tiesiskā atbildība. Zina. red. Ā. Meikališa. Rīga: LU Akadēmiskais apgāds, 2018, 275.-294. lpp.; Meikališa Ā. KPL 111.' panta komentārs. Grām.: Kriminālprocesa likuma komentāri. A dal̦a. Rìga: Latvijas Vēstnesis, 2019, 379.-385. lpp.
} 
“īpašnieks” / “valdītājs” / “lietotājs” u. c.), kas var izraisīt nevajadzīgas diskusijas, kā arī absolūti nepamatota koncentrēšanās tikai un vienīgi uz jau esošu aizskārumu kā pamatu aizskartā mantas īpašnieka statusa piešķiršanai. Statusa piešķiršana tikai tādai personai, kurai aizskārums jau ir radies, bet nepiešķiršana tām, kurām tas ir potenciāli iespējams, būtiski ierobežo šo personu tiesību aizsardzību: 1) liedz izteikties pirms lemšanas par aizskārumu, 2) liedz aktīvi piedalīties un 3) liedz efektīvi aizstāvēties pēc nolēmuma pieņemšanas. Kā īpaši spilgtus piemērus situācijām, kad aizskārums kriminālprocesā ir neesošs, taču potenciāli iespējams, var minēt kompensācijas un procesuālo izdevumu piedziṇu no vecākiem vai personām, kas tos aizvieto (KPL 353. un 368. pants), kā arī nearestētas "aizvietotājmantas" konfiskāciju (KL 70.14 panta ceturtā daḷa).

Šajā situācijā joprojām uzturams priekšlikums par aktīva kriminālprocesuāla statusa piešķiršanu ne tikai personām, kurām aizskārums ir jau esošs, bet arī tādām, kurām tas ir iespējams (dēvējot, piemēram, par mantisko jautājumu risinājumā ieinteresētām personām vai citādi). Šajā kontekstā daḷēja līdzìba saskatāma ar "trešo personu” institūtu civilprocesā un administratīvajā procesā, kur aktīva procesa dalībnieka tiesības tiek piešksirtas personām, kuru intereses varētu tikt aizskartas procesa gaitā vai rezultātā, vai arī ar Latvijas Kriminālprocesa kodeksa ${ }^{8}$ spēkā esamības laikā pazīstamo civilatbildētāja statusu. Jāatzīst gan, ka neviens no šiem institūtiem nevarētu tikt pārṇemts nemainītā formā, jo neaptvertu visus šodien pazīstamos aizskāruma gadỉjumus kriminālprocesā.

Paralēli gan risināms jautājums par to, vai un cik daudz vispār kriminālprocesā būtu jārisina tādi mantiski jautājumi, kuri skar ne tikai cietušā un noziedzīgā nodarījuma izdarītāja mantiskās intereses, bet tieši vai netieši attiecas arī uz citām personām. Sākotnēji, pieņemot KPL, varbūt bija pamats uzskatīt, ka mantiskās attiecības ir iespējams risināt, neiesaistot un nevērtējot citu, vienīgi iesaistīto personu intereses, bet, laikam ritot, redzam, ka tas nebūt tā nav. Spilgts apliecinājums tam ir judikatūras nolēmumi, piemēram, saistībā ar noziedzīgiem nodarījumiem ceḷu satiksmes jomā, kuros atzìts: "No vispārējās kārtības, kāda noteikta Kriminālprocesa likuma 26. nodạ̦ā, būtiski atšķiras kaitējuma kompensācijas saņemšanas kārtības regulējums cietušajiem, kas par tādiem atzīti Krimināllikuma 260. pantā paredzētajā noziedzīgajā nodarījumā, jo šajos gadījumos kaitējuma kompensācijas veidu, apmēru un saṇemšanas kārtību bez Kriminālprocesa likuma 26. nodaḷā ietvertajām normām, Civillikuma 1635. panta (2006. gada 26. janvāra likuma redakcijā) regulē arī speciālais likums (Sauszemes transportlīdzekḷu īpašnieku civiltiesiskās atbildības obligātās apdrošināšanas likums) un saskaṇā ar to izdotie Ministru kabineta noteikumi." Tā, piemēram, judikatūras nolēmumu bāzē ietverts 2017. gada Augstākās tiesas lēmums, kurā norādīts: “Turklāt, izlemjot jautājumu par morālā kaitējuma kompensāciju kriminālprocesos par Krimināllikuma 260. pantā paredzētā noziedzīgā nodarījuma izdarīšanu, apspriežams jautājums, vai konkrētajā lietā nav jāpiemēro Ceḷu satiksmes likuma normas, jo saskaṇā ar šā likuma 1. panta 24., 25., 29. punktā, 44. panta otrajā un trešajā daḷā noteikto par transportlīdzekḷa ekspluatācijas rezultātā nodarìto zaudējumu atbild transportlīdzekḷa īpašnieks, valdītājs vai

8 Latvijas Kriminālprocesa kodekss: LPSR likums. Pieņemts 01.04.1961. Zaudējis spēku 01.10.2005. Konsolidētā redakcijā uz spēka zaudēšanas brīdi pieejams: https://likumi.lv/doc.php?id=90971 
turētājs," "Kriminālprocesā no vainīgā var tikt piedzīti tie zaudējumi, kuri netiek atlīdzināti saskaņā ar Sauszemes transportlīdzekḷu īpašnieku civiltiesiskās atbildības obligātās apdrošināšanas likumu vai kuri pārsniedz šajā likumā un saskaṇā ar to izdotajos normatīvajos aktos noteikto apdrošinātāja atbildības limitu. Pārējos gadijjumos kaitējuma kompensāciju kriminālprocesā nenoteic."10 Protams, var norādìt, ka no apdrošinātājiem kriminālprocesa gaitā nekas netiek piedzìts, lìdz ar to viņus kriminālprocesā nav pamata iesaistìt, tomēr ir redzams, ka tiesām, lai saprastu, kādā apmērā piedzìt kompensāciju no apsūdzētā, ir jāizvērtē, cik tad būtu jāmaksā apdrošinātājam, lìdz ar to nevar teikt, ka viṇu intereses skartas netiek. No tā izriet secinājums, ka vai nu potenciāli aizskartajiem ir jāpiešksir kāds procesuāls statuss, vai arī jautājumi, kas ir saistīti ar kompensācijām, kuras paredzētas speciālajos likumos, atstājami kriminālprocesa gaitā bez izskatīšanas. Tāpat nevar nenorādīt, ka šis jautājums savu aktualitāti prognozējami paaugstinās, kaut vai attīstoties un rodoties arvien jauniem profesionālās darbības apdrošināšanas veidiem. Bez tam nevar neatzìt, ka zināmu soli tajā virzienā, ka kriminālprocesa gaitā kādas tiesības piešķiramas ne tikai mantas "īpašniekam” utt., bet arī citiem, likumdevējs jau spēra 2017. gadā, ${ }^{11} \mathrm{kad}$ ar grozījumiem KPL tā 361. pants tika papildināts ar septīto prim dalı: "Ja attiecībā uz mantu, kurai tiek uzlikts arests, ir reǵistrēta hipotēka vai komercḳīla, procesa virzìtājs par pieņemto lēmumu informē hipotekāro kreditoru vai komercḳilas ņēmēju. Saņemot informāciju par aresta uzlikšanu mantai, hipotekārajam kreditoram vai komercķilas ñēmējam ir tiesības iesniegt dokumentus par mantas izcelsmi."

Neskatoties uz to, ka šobrīd KPL nepamatoti liegta tādu personu interešu aizsardzība, kurām mantisko interešu aizskārums ir tikai iespējams, bet vēl nav esošs, pat tām, kuru intereses jau ir aizskartas, aizsardzība nav pilnīga. Joprojām kā aktuāls jautājums skatāma KPL paredzētā nepamatotā t. s. aizskartā mantas īpašnieka statusa dalǐšana tādos, kuru mantai ir uzlikts arests, un tādos, kuru mantai arests nav uzlikts. ${ }^{12}$ Redzam, ka saskaṇā ar KPL 111. ${ }^{1}$ pantu tām personām, kuru mantai arests uzlikts nav, kādas tiesības piešķirtas tikai pirmstiesas kriminālprocesā, bet ne iztiesāšanā. Jau esmu norādījusi iepriekš un savu viedokli nemainu arī šobrīd, ka šāda pieeja nav atbalstāma, jo liedz personai efektīvu savu tiesību aizsardzību. Tā l,oti spilgti izpaužas, piemēram, attiecībā uz citam, ne apsūdzētajam piederoša lietiskā pierādījuma konfiskāciju. Rīcība ar lietisko pierādijumu kriminālprocesa gaitā nav saistāma ar aresta uzlikšanu tam. Lìdz ar to, ja par lietisko pierādījumu atzīta manta nepieder apsūdzētajam, tad pirmstiesas kriminālprocesā tās īpašniekam kā kriminālprocesā aizskartās mantas īpašniekam ir noteikts tiesību loks, savukārt iztiesāšanā vairs nav

\footnotetext{
9 24.08.2017. Krimināllietu departamenta lēmums lietā Nr. SKK-488/2017. Pieejams: http://www.at.gov.lv/ lv/judikatura/judikaturas-nolemumu-arhivs/kriminallietu-departaments/klasifikators-pec-lietu-kategorijam/kriminalprocesa-likums/26nodala-ar-noziedzigo-nodarijumu-radita-kaitejuma-atlidzinasana-350-354pants [aplūkots 03.03.2020.].

10 21.01.2020. Krimināllietu departamenta lēmums lietā Nr. SKK-1/2020; 18.02.2020. Krimināllietu departamenta lēmums lietā Nr. SKK-93/2020. Pieejami: http://www.at.gov.lv/lv/judikatura/judikaturasnolemumu-arhivs/kriminallietu-departaments/klasifikators-pec-lietu-kategorijam/kriminalprocesalikums/26nodala-ar-noziedzigo-nodarijumu-radita-kaitejuma-atlidzinasana-350-354pants [aplūkots 03.03.2020.].

11 Grozījumi Kriminālprocesa likumā: LV likums. Pieņemts 22.06.2017.

12 Tika ieviesta ar 22.06.2017. gada grozijumiem KPL: Grozijumi Kriminālprocesa likumā: LV likums. Pieņemts 22.06.2017.
} 
(sk. KPL 111. ${ }^{1}$ pantu). Savulaik, motivējot, kāpēc lietiskā pierādījuma īpašniekiem nav nepieciešams piešķirt jebkādu kriminālprocesuālu statusu iztiesāšanā, Tieslietu ministrija norādīja: "Vienlaikus personām, kurām manta ir izṇemta kā lietiskie pierādījumi, būtu saglabājamas kriminālprocesā aizskartā mantas îpašnieka tiesības pirmstiesas kriminālprocesā. KPL (tajā skaitā plānotie grozījumi KPL 240. pantā) paredz, ka lietiskie pierādijumi, kas nepieder noziedzīgā nodarījuma izdarītājam, ir atdodami to îpašniekiem vai likumīgajiem valdītājiem. Turklāt KPL un Ministru kabineta 2011. gada 27. decembra noteikumi Nr. 1025 "Noteikumi par rīcību ar lietiskajiem pierādijumiem un arestēto mantu" paredz, ka gadījumos, ja lietiskais pierādỉjums ir jāatdod tā ìpašniekam vai likumīgajam valdītājam, bet to izdarìt nav iespējams, īpašniekam atlīdzina ar tās pašas sugas un tādas pašas kvalitātes priekšmetu vai samaksā to vērtību, kāda pastāv atlīdzināšanas dienā. Tādējādi nav saskatāms personas, kuras manta kriminālprocesa ietvaros izņemta kā lietiskais pierādijums, tiesību uz ìpašumu apdraudējums."13 Acīmredzami tika ignorēts fakts, ka lietiskais pierādījums var vienlaikus būt arī, piemēram, noziedzīga nodarījuma izdarīšanas rīks, kurš saskaṇā ar KPL 240. pantu var tikt konfiscēts. Latvijas likumdevēja nepārdomāto un netālredzīgo rīcību uzskatāmi demonstrē ne tikai nevēlēšanās sekot pašmāju zinātniekiem, bet arī neatbilstība jau tajā brīdī starptautisko cilvēktiesību institūcijās un Latvijas Augstākajā tiesā lemtajam. Uz to, ka personai, kuras manta (lietiskais pierādījums) kriminālprocesa gaitā var tikt konfiscēta, jāpieškiir aktīvas dalības tiesības arī iztiesāšanā, uzskatāmi norāda Eiropas Cilvēktiesību tiesas prakse. ${ }^{14}$ Arī mūsu vietējā judikatūrā šì nostāja, cita starpā atsaucoties uz Eiropas Cilvēktiesību tiesā lemto, tikusi nostiprināta jau 2016. gadā. ${ }^{15}$

Šìs raksta sadaḷas noslēgumā var izvirzìt vēl kādu līdz šim neizskanējušu atziṇu - proti, ir pamats atzìt, ka teorētiskas un praktiskas problēmas izraisa visu “aizskarto" kopēja reglamentācija, kā arī to (vismaz lielākās daḷas) atrašanās grupā "citi procesa dalībnieki". Pilnīgi iespējams, ka paralēli ieteikumam paplašināt to personu loku, kurām kriminālprocesā piešķirams atbilstošs statuss savu mantisko interešu efektīvai aizsardzībai, ir pamats izvirzìt priekšlikumu šos dalībniekus grupēt, ja ne likumā, tad vismaz teorijā. Pat šādam atzinumam ir l̦oti dažāda to jautājumu daba, kuru dēḷ attiecīgās personas var tikt iesaistītas kriminālprocesā (ir acīmredzami, ka, piemēram, kompensācijas maksāšanas pienākums ir stipri atšḳirīgs no, teiksim, prezumēti noziedzīgas mantas vai konfiscējamās mantas aizstājējmantas konfiskācijas vai lietiskā pierādījuma konfiskācijas). Tāpat veiksmīga nešķiet šobrīd KPL redzamā pieeja kriminālprocesā aizskarto mantas īpašnieku ievietot grupā "Citi procesa dalībnieki”, kas rada priekšstatu, ka tam nav patstāvīgu interešu kriminālprocesa rezultātā (kā, piemēram, lieciniekam vai speciālistam) un secīgi ka tā dalībai piešķirama vien

${ }^{13}$ Likumprojekta (Nr. 630/Lpl2) “Grozijumi Kriminālprocesa likumā” anotācija. Pieejams: https://titania. saeima.lv/LIVS12/SaeimaLIVS12.nsf/0/AB2871419A747C7FC2258011002DD2FA?OpenDocument [aplūkots 03.03.2020.].

14 Sk., piemēram: Lietas ÜNSPED PAKET SERVISI SAN. VE TIC. A. S. v. Bulgaria, pieteikums Nr. J503/08 (sk. http://hudoc.exec.coe.int/eng?i=004-3914) un Denisova and Moiseyeva v. Russia, pieteikums Nr. 16903/03 (sk. http://hudoc.exec.coe.int/eng?i=004-13757).

15 Sk. 20.04.2016. Krimināllietu departamenta lēmums lietā Nr. SKK-110/2016. Pieejams: http://at.gov. lv/lv/judikatura/judikaturas-nolemumu-arhivs/kriminallietu-departaments/klasifikators-pec-lietu-kategorijam/kriminalprocesa-likums/12nodala-riciba-ar-lietiskajiem-pieradijumiem-un-dokumentiem235-240pants [aplūkots 03.03.2020.]. 
epizodiska, ne patstāvīga un nozīmīga loma. Aicinājuma pārskatìt šo nostāju un salīdzinājuma ilustrācijai var noderēt pieeja, kas redzama citos procesuālajos likumos - tā, piemēram, CPL un APL “trešās personas" iekḷautas sadaḷā "Lietas dalībnieki”, pagaidām vēl spēkā neesošajā (paredzamais spēkā stāšanās datums 01.07.2020.) Administratīvās atbildības likumā ${ }^{16}$ aizskartās mantas ìpašnieks ierindots pie lietas dalībniekiem un nevis pie "citām personām" (sk. šì likuma 39. pantu).

\section{Secinājumi}

1. KPL esošais "kriminālprocesā aizskartā mantas īpašnieka” procesuālais statuss, no vienas puses, neaptver visas tās personas, kuru mantiskās intereses tieši var skart kriminālprocesa gaitā un rezultātā, tai pašā laikā, no otras puses, aptver procesa dalībniekus ar būtiski atšķirīgām iezīmēm. Tas l̦auj atzìt, ka šì institūta izveide nav bijusi veiksmīga un tā tālākas ilgtspējīgas attīstības nodrošināšanai nepieciešama kardināla tā reforma.

2. Kriminālprocesā aizskartā mantas ìpašnieka iekl̦aušana procesa dalỉbnieku klasifikācijas kategorijā "citi procesa dalïbnieki" teorētiski var tikt apšaubìta un var radìt maldīgu priekšstatu par šì dalībnieka procesuālo nozìmi, ņemot vērā šì dalībnieka būtisko procesuālo ieinteresētību kriminālprocesa rezultātā.

3. Esošais kriminālprocesā aizskarto mantas īpašnieku iedalījums tādos, kuru mantai ir, un tādos, kuru mantai nav uzlikts arests, nav uzskatāms par pamatotu. Tiesību uz aktīvu dalību tiesā (kā arī no tām izrietošo pārsūdzības tiesību) nepiešķiršana tām personām, kuru mantai arests nav uzlikts, taču kuru mantiskās intereses potenciāli var tikt tieši skartas ar tiesas nolēmumu, nenodrošina šo personu interešu pilnvērtīgu tiesisko aizsardzību.

16 Administratīvās atbildỉbas likums: LV likums. Pieņemts 25.10.2018. 